\title{
THE PROTEIN AND NON-PROTEIN FRACTIONS OF SOME SAMPLES OF WOMAN'S MILK
}

BY

ANGELIA M. COURTNEY, B.A., and ALAN BROWN, M.B.

(From the Sub-Department of Pædiatrics, University of Toronto, and the Hospital for Sick Children, Toronto.)

A considerable number of large samples of woman's milk which was supposed to be the cause of the poor condition of the infants taking it have recently been analyzed at the Hospital for Sick Children to determine whether or not there was an abnormally high or low concentration of one or more of the salt constituents. The fat and total nitrogen content were also estimated in the samples when sufficient milk was available. The fat content was frequently found to be lower than normal but the nitrogen content, though tending to be slightly lower than average, never ran beyond normal limits. While this work was in progress the question arose whether the nitrogen distribution into the casein, lactalbumin and globulin, and non-protein nitrogen fractions might not in some cases show unusual values. Accordingly a series of determinations was made, not only in as many of the supposedly abnormal milks as possible but in a large number of samples of milk from wet nurses supplying the infant wards.

The nitrogen distribution commonly taken as normal is that ascribed to Schlossman as quoted by Rietschel ${ }^{1}$ :-casein 41 per cent., lactalbumin and globulin 44 to 39 per cent., and residual nitrogen 15 to 20 per cent. Munk ${ }^{2}$ is said to be the first to have called attention to the non-protein fraction, which is reported as about half in the form of urea and a large part of the remainder in amino-acids. The most complete contributions to the subject of the nonprotein nitrogen fraction of woman's milk have been made by Frehn ${ }^{3}$ and by Denis, Talbot and Minot. There has been other valuable work on the subject by Macy et al. ${ }^{5}$, Mader ${ }^{6}$, Spirito ${ }^{7}$, Giaume ${ }^{8}$, besides a good many investigations into the difference between the acid and the rennet precipitation of the protein. Denis et al. ${ }^{4}$ found a non-protein nitrogen content of $\cdot 020$ to $\cdot 040 \mathrm{mgrm}$. per 100 c.cm. milk, which on the basis of an average total nitrogen content would be about 10 to 20 per cent. of total nitrogen. Frehn ${ }^{3}$ reports $16 \cdot 0$ to $23 \cdot 2$ per cent. of total nitrogen as non-protein nitrogen. Macy et al..$^{5}$ give a value of 15 to 20 per cent. The values of Denis et al. seem to be a little lower than those of other investigators. They obtained the protein-free filtrate by precipitation first with copper sulphate, then a second precipitation in that filtrate 
with calcium hydroxide and the removal of excess calcium as oxalate. This method was used in order to remove sugar and fat as well as protein, in preparation for applying their methods for estimating urea, amino-acids, etc. So far as could be ascertained the non-protein nitrogen fraction of the other investigators is the nitrogen content of the filtrate after precipitation in the milk with phosphotungstic acid. In the work here reported tannic acid was used as the protein precipitant, according to the procedure of L. L. Van Slyke ${ }^{9}$. It is claimed that cystin and the three basic amino-acids, lysin, arginin and histidin, are precipitated by phosphotungstic acid, as shown by $\mathbf{D}$. D. Van Slyke in his scheme for the hydrolysis of proteins ${ }^{10}$. In a number of the milks analyzed in this study tannic acid and phosphotungstic acid were each employed as precipitant. In all these the nitrogen content of the tannic acid filtrate was greater than that of the phosphotungstic acid filtrate by 0.5 to 6.0 per cent. of total nitrogen, the average being about 2 per cent.

METHONS EMPLOYED.-The complete procedure in this study was as follows :-

$20 \mathrm{c.cm}$. of milk was accurately measured into a $50 \mathrm{c.cm}$. volumetric flask and diluted with distilled water about 1 in 2,2 c.cm. of 2 per cent. acetic acid were added slowly with shaking, and the stoppered flask was allowed to stand in the cold for twelve hours or more. After being made to volume, the contents were filtered through a dry high grade filter paper and samples were measured out for total nitrogen estimation according to the Kjeldahl-Gunning method. The remainder of the filtrate was gently boiled for 2 minutes, the lost water was restored and as large samples as possible were measured out for nitrogen estimation. Total nitrogen was also determined in $5 \mathrm{c.cm}$. samples of the original milk. When there was abundance of milk $40 \mathrm{c.cm}$. samples were measured into $100 \mathrm{c} . \mathrm{cm}$. flasks for the first precipitation and acid added in proportion to the amount of milk used. With a few of the milks it was impossible to get a clear filtrate after the first precipitation. In such cases the values for the casein and the lactalbumin fractions have been omitted from the report. Usually the filtrate from the second precipitation was clear, sometimes faintly opalescent. It was assumed that the value found for total nitrogen, less that for the nitrogen in the first filtrate, gave the value for casein nitrogen, and the difference between the nitrogen values of the first and second filtrates gave the value for lactalbumin and globulin nitrogen. The filtrate obtained after boiling the acidified milk always contained more nitrogen than the tannic acid precipitate did. In 6 samples, in the filtrate obtained after boiling, a further precipitation was carried out with 50 per cent. sulphuric acid and saturation with zinc sulphate at $70^{\circ} \mathrm{C}$. The filtrate obtained after this treatment contained distinctly less nitrogen than that present in the filtrate after boiling. The nitrogen removed by the sulphuric acid and zinc sulphate precipitation should represent a proteose fraction. Probably in some instances it included also nitrogen corresponding to part of the casein and lactalbumin fractions not completely removed by the first and second precipitations. The tannic acid precipitation was carried out by measuring $20 \mathrm{c.cm}$. of milk into a $100 \mathrm{c.cm}$. volumetric flask, diluting the milk about 1 in 3 , adding approximately $\frac{1}{2}$-grm. of sodium chloride and 12 per cent. tannic acid drop by drop until no more precipitate could be seen to form. After being allowed to stand for an half hour or longer, the contents were made to volume, filtered, and samples of the filtrate were measured out for nitrogen estimation'. The phosphotungstic acid separation was performed by adding to a measured amount of milk in a volumetric flask, for example, $20 \mathrm{c.cm}$. in a $50 \mathrm{c.cm}$. flask, one half the volume of 10 per cent phosphotungstic acid in 2 per cent. hydrochloric acid, allowing it to stand a short time, filtering and estimating nitrogen in filtrate.

This series of separations was carried out on thirty-six samples of milk of wet nurses, 1 to 5 samples from each of fourteen women and two composite samples. There was no definite reason to suspect these milks of being abnormal in any respect, since the infants taking them were doing as well as was to be expected. The same estimations were made in thirteen samples of milk 
which appeared not to agree with the infants taking the milk. In four casos the infants were suffering from tetany and rickets; or rickets alone. With the others there were various unfavourable symptoms supposedly. due to taking the mother's milk, such as convulsions not due to tetany, diarrhœa, failure to gain, and in one instance eczema.

When more than one sample of milk from the same woman was analyzed, the average of all the values found was used in the table. That the different samples from the same woman usually showed closely agreeing values at least suggests that the first and second precipitates usually represented pretty definite fractions of the nitrogen content.

The values found for the milks presumably normal are given in the upper half of the table, the other below. It is seen that very little distinction can be made between the values for the two groups. One only among the abnormal milks shows a divergence beyond the range of the values for the normal samples, that designated " Ka," in which the nitrogen content of both the tannic acid and phosphotungstic acid filtrates was much greater than that of any of the other samples. The infant taking this milk was suffering from eczema and improved on removal from the breast. Unfortunately fat and salt estimations were not made in this milk, so that other possible causes for the apparent harmful effect of the milk cannot be ruled out.

In most of the other milks not agreeing with the infants extreme abnormalities were found in the content of fat or of one or more of the salt constituents.

Thus it is seen that with one possible exception this entire series can be taken as showing a normal range of values for the casein, the combined lactalbumin and globulin, and the non-protein nitrogen fractions of the nitrogen content of mother's milk.

Though the investigation yielded negative results in the sense of not affording an explanation in certain cases in which mother's milk had an unfavourable effect, the results seem to be worth reporting if only for the purpose of again calling the attention of pædiatrists to the large proportion of the nitrogen of woman's milk which is not in the form of protein, and which, according to Munk and to Denis et al., is about 50 per cent. in the form of urea.

This proportion is far greater than that of the same fraction of cow's milk, though the actual quantity, mgrm. per $100 \mathrm{c.cm}$. is about the same in both, according to results obtained in this laboratory as well as those reported by Denis and Minot ${ }^{11}$. We found for the average in thirteen samples of cows' milk (herd milk) $7 \cdot 2$ per cent. of total nitrogen in the tannic acid filtrate and $5 \cdot 4$ per cent. in the phosphotungstic acid filtrate. As cows' milk contains from two to three times, usually nearer three times, as much nitrogen as woman's milk, it can be seen that the actual amount present must be nearly the same in both kinds of milk.

Another point brought out by this study is the difference between the nitrogen content of the filtrate after precipitation in the milk by tannic acid and the content after precipitation by phosphotungstic acid, this difference being presumably a measure of the content of cystin and the basic aminoacids, lysin, arginin and histidin. The thirteen samples in which this was 
estimated showed a variation, as above stated, of from 0.5 to 6.3 per cent. of total nitrogen, the extremes being found in samples which were normal as judged by the condition of the infants taking the milk. Whether this varying content could have any significance in connection with the well-being of the infant is a question which would require a much more extended investigation than this to determine. That such an investigation might be worth undertaking is suggested by the importance for growth of some of these amino-acids.

\section{Summary.}

1. A partial nitrogen partition was carried out on a series of samples of woman's milk, part of them supposedly normal and part supposedly abnormal in some respect. With one possible exception the nitrogen partition showed no distinctions between the two groups. The total nitrogen content ran slightly lower than the usually accepted average. The casein fraction of total nitrogen ranged from 9.7 to 49.2 per cent. of total nitrogen (average 31.8 per cent.), and the lactalbumin and globulin fraction from $19 \cdot 0$ to $57 \cdot 7$ per cent. (average 31.6 per cent.). Total non-protein nitrogen, that remaining after precipitation of protein by tannic acid, ranged from 11.0 to 27.5 per cent., with one possibly abnormal value of 42.0 per cent. (average 21.9 per cent. of total nitrogen). The non-protein nitrogen remaining after precipitation with phosphotungstic acid ranged from $11 \cdot 2$ to $22 \cdot 3$ per cent. of total nitrogen, with $36 \cdot 4$ per cent. in the possibly abnormal sample (average 19.8 per cent.). The difference between the last two averages, $2 \cdot 1$ per cent. of total nitrogen, represents the content of cystin and the basic amino-acids, lysin, arginin and histidin.

2. The large proportion of the nitrogen content of woman's milk in the form of non-protein nitrogen is emphasized.

\section{REFERENCES.}

1. Rietschel, H., Jahrb. f. Kinderh., Berlin, 1906, LXIV, 125.

2. Munk, Virch. Arch. f. path. Anat., Berlin, 1893, CXXXIV, 501.

3. Frehn, A., Z. f. physiol. Chem., Berlin, LXV, 256.

4. Denis, W., Talbot, F. B., \& Minot, A. S., J. Biol. Chem., N.Y., 1919, XXXIX. 47

5. Macy, I. G., Outhouse, J., Long, M. L., Brown, M., Hunscher, H., \& Hoobler, B. R., Loc. cit., 1927, XXXI, Supp., 74.

6. Mader, A., Jahrb. f. Kinderh., Berlin, 1923, CI, 281.

7. Spirito, F., Pediatria, Naples, 1926, XXXIV, 921.

8. Giaume, C., Loc. cit., 1927, XXXV, 1114.

9. Van Slyke, L.L., N.Y. Exp. Station Bull., N.Y., CCXV, 102.

10. Van Slyke, I.D., N.Y. Med. J., N.Y., 1912, Aug. 10 and 17.

11. Denis, W., \& Minot, A. S., J. Biol. Chem., N.Y., 1919, XXXVIII, 453. 
TABLE

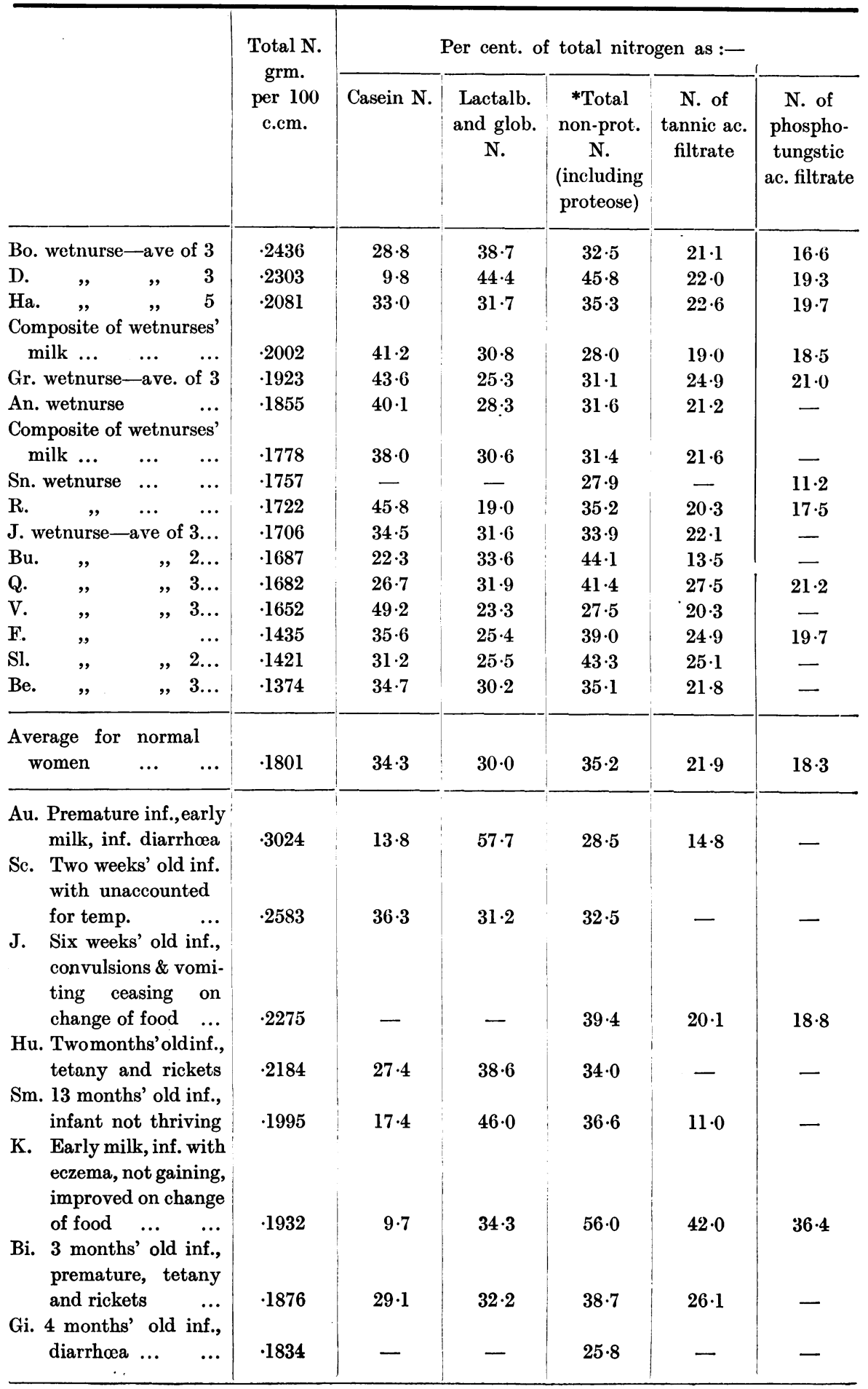


TABLE-continued.

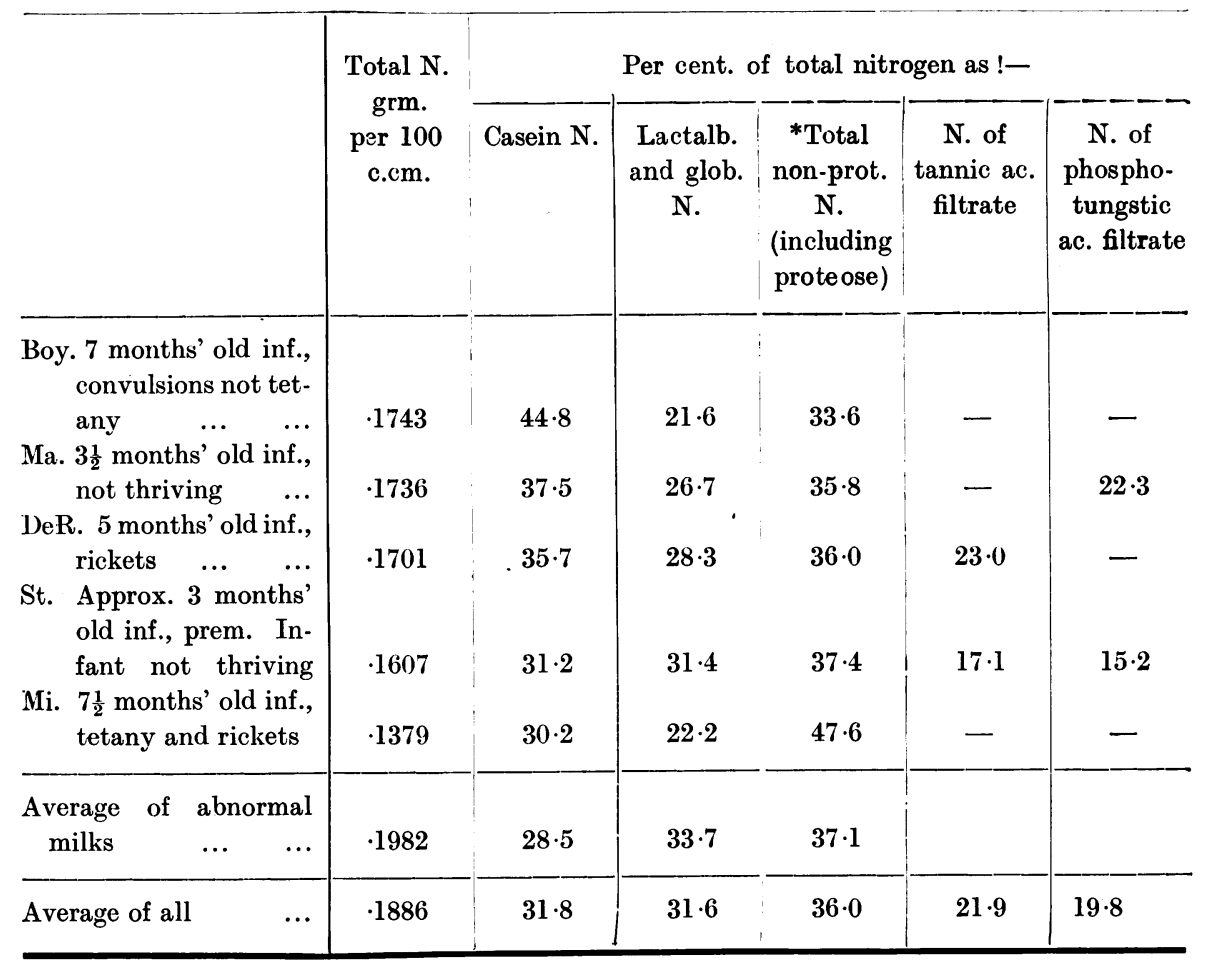

*This may also include some nitrogen belonging to protein not brought down in the precipita. tions. 